
\title{
25 Research Square \\ Ethnobotanical Characterization of Scarlet Eggplant (Solanum Aethiopicum L.) Varieties Cultivated in Benin Republic
}

\section{Scholastique Aguessy \\ UNSTIM}

\section{Roger Idossou}

UNSTM

\begin{abstract}
Anicet Gbèblonoudo Dassou ( $\square$ dassoua5@gmail.com )
National University of Sciences, Technology, Engineering and Mathematics https://orcid.org/0000-0002-
\end{abstract} 6629-4262

\section{Yêyinou Laura Estelle Loko}

UNSTIM

\section{Octaviano Igor Yelome}

UNSTIM

Anicet A. Gbaguidi

UNSTIM

\section{Paterne A. Agre}

UNSTIM

Alexandre Dansi

UNSTIM

Clément Agbangla

UNSTIM

\section{Research}

Keywords: African scarlet eggplant, preference criteria, production constraints, varietal diversity, Benin

Posted Date: January 15th, 2021

DOl: https://doi.org/10.21203/rs.3.rs-139061/v1

License: @ (i) This work is licensed under a Creative Commons Attribution 4.0 International License. Read Full License 


\section{Abstract}

Background: The African eggplant [Solanum aethiopicum (L.)] is an important orphan traditional vegetable cultivated in tropical regions for its edible fruits. In Benin republic, S. aethiopicum (L.) is mainly produced by rural farmers for food and for its uses in traditional medicine. Assessing the varietal diversity, the endogenous knowledge, the production constraints and the farmers' preference criteria are of great importance for promotion and conservation purposes.

Methods: Using rural appraisal tools and methods, an ethnobotanical study was conducted within 680 households across 92 villages. A total of 60 local accessions were identified, documented and collected in the surveyed sites.

Results: We documented fifteen (15) farmers' criteria for agronomic (57.88\% of responses), and culinary (28.51\%) preference; and for economic (13.61\%) aspects. Several constraints related to eggplant production in Benin were recorded among which, low market demand ( $27 \%$ of responses), lack of high-yielding cultivars ( $11.08 \%$ of responses), low fruit storability $(10.67 \%)$, low productivity $(9.84 \%)$, soil poverty $(8.43 \%)$, susceptibility to high soil moisture ( $8.02 \%)$, pests $(9.56 \%)$ and diseases $(8.45 \%)$, and drought $(6.38 \%)$ appeared to be the most important stress factors. In addition to synthetic pesticides, the eggplant farmers use botanical plant extracts such as extracts from Azadirachta indica (Meliaceae) and Hyptis suaveolens (Lamiaceae).

Conclusion and implications: Benin eggplant production still remains traditional and limited to a few rural farmers. Finally, the current collected germplasm was proposed for further evaluation using morphological and molecular markers in order to provide breeders with traits of interest for developing better eggplant varieties that are suitable for local environmental conditions and production systems.

\section{Background}

The scarlet eggplant (Solanum aethiopicum L.; family: Solanaceae) is one of the indigenous vegetable species grown in African countries. S. aethiopicum is the second most widespread cultivated eggplant, occurring in Africa, and in some parts of Caribbean, Brazil and southern Italy [1, 2]. Its production in Africa has significantly increased from 606,672 tons in 1994 to 2,079,920 in 2018 [3]. S. aethiopicum contains essentials micronutrients (Fibre, Carbohydrate, Proteine, Fat etc), vitamins (A; B1, 2, 6, 12; C, D) and proteins that are crucial for human good health $[4,5]$. S. aethiopicum is also known to have several medicinal properties and is sometime listed as nutraceutical [6, 7]. The Igbo people in Nigeria community can hardly do without eating garden egg because it is good for the sight. In a study to assess the effects of garden egg on some visual functions of visually active Igbos of Nigeriall, the experts found that the consumption of garden egg fruits may be of great benefits to glaucoma patients [8]. According to $[9,10]$, a frequent consumption of this vegetable can reduce blood pressure and prevent heart disease. S. aethiopicum is was reported to be an important source of resistance to several pests [11] and diseases [12]. Four cultivar-groups have been recognized in $S$. aethiopicum, and include Gilo, Shum, Kumba and Aculeatum [13, 14].

In Benin republic, S. aethiopicum occurs across the whole country and on a small scale in home gardens [15]. It's one of neglected and underutilized crop and there is no national research program deeply conducted for its 
promotion. It relates to so-called neglected and under-utilized crops because they are locally abundant in developing countries, rare on a scale $[16,14]$ and there is a low level of research investments in their favor compared to those made for dominant crops. Their potential is also untapped as a means of subsistence [17].

With the notable exception of the study by [18] on mite pests, there is no single article presenting not only an exhaustive list of cultivated eggplant of Benin but also their local name, production constraints (including pests and diseases), cultural characteristics, extent and distribution, not even the farmers' preference criteria. This paper thus presents the results of a survey on the ethnobotany of cultivated scarlet eggplant in Benin. Ethnobotanical knowledge of Benin eggplant genetic resources will facilitate their conservation and use in further studies and breeding programs $[19,20]$. Ethnobotanical research will help to address the characteristics of traditional knowledge to establish priorities together with the local communities as to ensure that local values are translated into rational uses of resources and effective conservation of the eggplant diversity and cultural knowledge [21]. Our expedition will thus be spent building a relationship between the communities to make the effort to understand their needs so that the research conducted will be mutually beneficial. The objectives of this study were fourfold:

- Map the eggplant production zones in the republic of Benin

- Assess the diversity, distribution and extent of the scarlet eggplant accessions in Benin

- Prioritize the production constraints and factors that affect the accessions diversity of Benin scarlet eggplant production

- Identify farmers' varietal preference criteria across agroecological and ethnic zones of Benin for breeding programs and development actions

\section{Methods}

\section{The study area and Sites selection}

The study was conducted in the Republic of Benin located in West Africa in the Gulf of Guinea, between latitudes $6^{\circ} 15^{\prime}$ and $12^{\circ} 26^{\prime} \mathrm{N}$ and longitudes $0^{\circ} 45^{\prime}$ and $3^{\circ} 52^{\prime} \mathrm{E}$ [22]. The country covers a total land area of $112,622 \mathrm{~km}^{2}$ with a population estimated at about 11,541,297 Inhabitants [23]. Administratively, Benin has twelve (12) departments [22]. The Beninese population is distributed around nine (09 sociolinguistic groups which are: Adja and related, Fon and related, Batonum and related, Dendi and related, Yoa / Lokpa and related, Peulh and related, Gua / Otamri and related, Yoruba and related and minority groups called Others (Zerma Haoussa Cotimba) [24].

On the scale of the year, the average precipitations vary from $700 \mathrm{~mm}$ (extreme North) to $1500 \mathrm{~mm}$ (extreme South-East), while the air temperatures vary on average around $27.2^{\circ} \mathrm{C}$, with absolute maxima that can exceed $45^{\circ} \mathrm{C}$ in the North. It should be noted that, for three decades, the rainfall regimes characterizing the climates of Benin have undergone sometimes very marked fluctuations at the heart of the seasons [22]. The plant species were estimated at $2807[25,26]$. Vegetation types are semi-deciduous forest (South), woodland and savannah woodland (Centre-East and Northeast), dry semi deciduous forest (Centre-West and south northwest) and tree and shrub savannahs (far north) [25]. 
Ninety-two (92) villages (Table 1; Figure 1) located in diverse agro-ecological (humid, semi-arid, arid) and ethnic zones across 10 administrative departments (Alibori, Atacora, Borgou, Collines, Couffo, Donga, Mono, Ouémé, Plateau, Zou) were surveyed in this study, which were estimated to cover the whole country in order to establish an exhaustive collection. Villages to be surveyed within departments were indicated by the officers of the national extension services of the ministry of agriculture operating in the departments. Prior to the survey, major markets of each department were also visited to collect from the scarlet eggplant sellers some indications about the potential villages to consider. 15 to 39 villages were considered per department.

\section{Ethnobotanical investigation}

Data were collected during our expeditions from appropriate locations by using the Participatory Research Appraisal tools and methods such as direct observation, group discussions, individual interviews and field visits through a questionnaire [27, 28, 29]. Interviews were conducted with the assistance of local translators from each area. As vegetable is mainly women's affair, they were the principal respondents in this study although men were not excluded. In each site, local women's organisations were directly involved in the study to facilitate the meetings organization and data collection. Prior to the meetings, farmers were requested in advance to bring samples of the varieties they used or knew about. The characteristics of the surveyed areas (agro-ecological zone, name of location, name of sub-location, name of village, ethnic group) were first collected after giving detailed presentation of our research objectives to the local farmers. Then, farmers were asked to list (vernacular name) and display the different types of varieties produced and/or consumed in their village. Group discussions allowed us to gather key information about the characteristics of the eggplant varieties inventoried. These include the local names, distribution and extent, cultural practices and seeds management, agronomic and culinary preference traits, production constraints, major pests and diseases, degree of consumption, perceived nutritional value, cultural importance and medicinal properties. Pictures were taken to use for catalogue and report writing. Field (home gardens, cultivated fields) visits were conducted to investigate farmers' varieties under cultivation in their natural habitat. The eggplant varieties were classified by local farmers according to their morphological traits.

Using the matrix scoring technique [30] and on an individual basis, varieties were ranked and the preference criteria identified and prioritized. Individual interviews were conducted in each site together with 20 producers (men and women) of different ages randomly selected in different households with the help of village leaders. Their socio-demographic data (gender, age, education level, and experience in scarlet eggplant production) were taken into account as a starting point of the discussions kept open-ended and unlimited to allow farmers to easily express their knowledge by following [31].

\section{Inventory, geographic distribution, and extent of eggplant accessions}

During the varietal inventory process, farmers were asked to list all the scarlet eggplant accessions occurring in their village (supporting sample). Prior, farmers were informed to kindly bring with them few samples of eggplant accessions when attending the meeting. Geographic distribution and extent of cultivated eggplant accessions were assessed by using the participatory four-square analysis methods according to [32]. Discussions were held to identify the traits of interest of each accession and to understand the farmers' contribution to the eggplant value chain of Benin. The main reasons why few or many households tend to grow certain accessions on small or large surfaces were noted. This method of four-square analysis would 
lead to the identification of potential high-performing accessions $(++)$. It would also allow us to evaluate the rate of varietal diversity threatened of disappearance out of the total of eggplant accessions cultivated by few households on small areas (- -).

\section{Assess the eggplant production constraints and farmer preference criteria}

Group surveys were conducted in order to identify and prioritize the farmer's preference according to [33]. Farmers were asked to enumerate a number of good characteristics scarlet eggplant should have to be widely adopted for farming in their village. The different criteria were then ranked using the progressive elimination method described in [34]. Farmers were requested to list in their local language all the constraints that limit the eggplant cultivation in their environment. The cited constraints were then prioritized according to their importance.

\section{Investigate the pests and diseases of scarlet eggplant and their farmers' management methods}

Pests and diseases damage to the scarlet eggplants and farmers' perceptions of these constraints as well were documented using group surveys in each village. Prior the survey, literature documentation was used to print out photos of the pest and disease symptoms for demonstration in farmers' field. Visits were then organized in four farmers' fields randomly chosen from the villages where pests and diseases were reported. These visits allowed us to evaluate the occurrence and damage of pests and diseases in the field with help from farmers and the IPGRI official descriptor for eggplants [35]. Then, the pests and diseases incidence was assessed with regard to the extent of the damage following [36] by using the 0-5 scale of IPGRI where: $0=$ no symptom was observed; $1=1$ to $10 \%$ of plant in the field are lowly infested; $2=10$ to $25 \%$ of the scored plant are infested; $3=26$ to $50 \%$ of the scored plant are infested; $4=51$ to $75 \%$ of the scored plant are infested; $5=$ more than $75 \%$ of the scored plant are infested.

\section{Data analysis}

Socio-demographical data (ethnic groups, genders, age, religions, education level, experiences in eggplant production, and activities) and farmers' perception on different attributes of scarlet eggplant production (preference traits, constraint of production, seeds management) were analyzed by using descriptive statistics (mean, percentage of responses or frequency, etc.). In order to estimate the eggplant varietal diversity across the studied three agro-ecological zones of Benin, Shannon-Weaver diversity index $(\mathrm{H})$ was calculated according to the following formula:

$$
H=-\sum P i \log P i
$$

With $P i=n i / N ; n i=$ number of accessions in each village; $N=$ Sum of $n i$ across the survey area.

Analysis of variance (ANOVA) was used to reveal significant differences between surveyed locations (villages) and among ethnic groups studied for the number of total accessions collected, the farmers' varietal preference, and production constraints. Socio-demographic parameters (age, gender, experiences and education level) were summarized in descriptive tables and graphics. In order to classify the collected accessions according to 
farmers' criteria, a Multiple Correspondence Analysis (MCA) was performed. The principal factors from the MCA were used to perform the Hierarchical Cluster Analysis (HCA) using cluster analysis [37] packages within R software [38].

Pests and diseases data were statistically analyzed by calculating the incidence (Inc) and mean severity (MS). The following formulas were used [39]:

$$
\text { Inc }=\frac{\sum_{i=1}^{n} I P}{\sum_{i=1}^{n} P S} \times 100
$$

$$
M S=\frac{\sum_{i=1}^{n} \mathrm{~s}}{\sum_{\mathrm{i}=1}^{\mathrm{n}} \mathrm{IP}}
$$

with IP number of infested plant and PS disease scored.

\author{
with S score of infested plants and IP Infested Plants
}

\section{Results}

\section{Socio-demographic characteristics of the respondents}

Results of this survey showed that out of the 680 respondents, only $28.16 \%$ were males, whereas majority $(71.84 \%)$ was females. The majority of the respondents $(66.73 \%)$ was illiterate with no school education (Table 1). There were $20.84 \%$ of the respondent that have a minimum level of primary education level, $10.56 \%$ were of secondary education level, whereas only $1.87 \%$ were found to be of higher education. The surveyed population was dominated by elder farmers ( 50 to 70 years old) representing $46.76 \%$ with a work experience of 11 to 20 years $(44.51 \%)$ in scarlet eggplant production. The surveyed farmers were reported to practice different activities among which crop production/agriculture was found to be the first activity (68.65\%) in the villages. Most eggplant farmers in this study were found to be Christians (36.94\%), Muslims (38.38\%) and animists $(24.68 \%)$.

\section{Scarlet eggplant production across ethnic groups}

Eggplant production was not widespread acceptance amongst $76.88 \%$ of the total interviewed farmers (Table 2). Eggplant distribution varied from one locality to another and from one farmer to another as well. This attests that local diversity and availability of eggplant on the local market are being destroyed. Very few farmers (13.36\%) in some locations are attempting to increase their eggplant collection, whereas $9.76 \%$ of local farmers were seen to have just maintained eggplant diversity within their area. Despite the fact that scarlet eggplant production was not truly well distributed in Benin, our surveys revealed a high ethnic diversity within communities. Adja ethnic group located in department of Mono and Couffo in southern region was found to be the first scarlet eggplant producer in term of land allocated (Table 2).

\section{Diversity of cultivated scarlet eggplants and their distribution}

In the study area, the scarlet eggplant showed a low varietal diversity ranging from 1 to 3 accessions per village (Table 3). An average of two scarlet eggplant accessions was recorded in each surveyed village. It 
appeared that no variety was produced by many households and on large scale cultivation (Table 3) except Gboyigouroto who truly spread the eggplant production in Yovogahoue village located in southern Benin. The Shannon-Weaver diversity index calculated $(\mathrm{H})$ varied from low to medium varietal diversity ranging from 1.22 to 3.88 scores across Benin villages (Table 4). The scarlet eggplant diversity was found to be very low in Zou and Ouémé departments, low in Borgou and Donga and medium in certain regions of Atacora, Couffo, Mono, Plateau and Collines (Table 4). Four morphotypes were identified based on the different morphological characteristics of eggplants accessions listed by farmers (color, shape, size, taste of the fruit, number of lobes) (Figure 2 and 3).All these four morphotypes was found in northern Benin, whereas only two morphotypes occur in the central and southern part of the country.

\section{Cultural practices of scarlet eggplant}

The results of this study showed that the scarlet eggplant is mainly produced during the normal rainy seasons (87.45\% of responses) which extend in south from mid-September to October and, in both north and center, from June to September. Off-season cultivation ( $12.55 \%$ of responses) is practiced during the dry seasons precisely from November to April and from mid-July to mid-September in the southern part and from November to April in the central and northern parts of the country.

Only $15 \%$ of interviewed farmers practiced direct sowing of eggplant seeds, whereas the majority ( $85 \%)$ adopted the pre-nursery culture methods. Most of farmers (75.46\%) admitted to use NKP and Urea fertilizers a few days before transplanting in order to compensate soil deficiency conditions in some regions (Centre and North). Organic manures (24.54\% of responses) were also applied.

\section{Scarlet eggplant production systems}

The traditional farming systems as practiced by the surveyed farmers can be classified into three categories. The first category included $50.81 \%$ of farmers who cultivated Solanum aethiopicum in home gardens in association with other vegetables such as Solanum lycopersicum, Capsicum annuum, Corchorus olitorius, Abelmoschus esculentus, Amaranthus spp.. In the departments of Ouémé, Plateau and Collines, the cultivation of eggplant in a home garden was much more observed. In the latter regions, the eggplant crop production was used for food consumption due to the low and poor demand at the market level. The second category included $28.52 \%$ of farmers who practice mixed cultures on farm. In this system, S. aethiopicum was found to be the main crop, whereas Zea mays (sown in a band) and Manihot esculenta (cultivated on the edge) were grown as secondary crops. The third category included $20.67 \%$ of farmers who practice monoculture in optimal density on farm.

\section{Scarlet eggplant pests and diseases and management methods}

Three major diseases and pests were reported in this study (Table 5). The eggplant diseases included bacterial wilt ( $50 \%$ of responses), dry crown rot ( $40 \%$ of responses) and gall nematodes ( $10 \%$ of responses). Among the eggplant pests we found stinking locusts ( $40 \%$ of responses), fruit and flower borers (32\% of responses) and caterpillars ( $28 \%$ of responses). The most significant diseases damages was fruits cracking $(29.16 \%)$ followed by fruits gallery $(12.57 \%)$. Leaf perforation $(23.49 \%)$ and inflorescence falling $(34.78 \%)$ were found to be the most significant pests damages. The incidence and severity scores varied according to the regions. The 
highest incidence score was recorded in southern region (40\%), followed by northern (33.33\%) and central (20\%) part of Benin. The mean severity indexes were found to be greater than 1 ( 1 for No disease; $2=1$ to $25 \%$ diseased, 26 to $50 \%$ diseased, 4= 51 to $75 \%$ infested, 5 for uper than $75 \%$ ) in all regions where those pests and diseases were recorded. In the fields, farmers use synthetic pesticides against pests. On the other hand, in home gardens, these are generally traditional methods such as the application of extracts from leaves (52.21\%), wood ash (33.43\%) and local metal fences (14.36\%) which are practiced to control pests and diseases. Most farmers use extracts from leaves of Azadirachta indica (Méliaceae) and Hyptis suaveolens (Lamiaceae) in the south Benin (25.05\% and $21.16 \%$ of interviewed farmers, respectively) and in the north (22.16\% and $22.25 \%$ of interviewed farmers, respectively) for pests and diseases control in the field. Only $H$. suaveolens is used by few farmers in the center (13.80\%). Wood ashes are highly used in the center (16.23\%) when compared to the south (11.16\%) and the north (6.04\%). Leaves extracts and wood ashes are used by spraying the eggplant leaves and flowers. Wire fences are exclusively used in home gardens against animals.

\section{Seed acquisition and conservation strategies}

Self-production (crop retention) of eggplant seeds was the main mode of seed supply adopted by majority of Benin farmers (82.23\%). The choice of seed retained for the next production season was mainly based on the size (33.22\%) and shape (24.65\%) of eggplant fruits. Farmers (42.13\%) also make selection of good quality first fruits. After physiological maturity of these fruits they dedicate them to sowing the next eggplant generations. There was no relevant information on the acquisition of seeds by inheritance (7.09\%), donation (6.32\%), purchase (3.11\%) and exchange (1.25\%) in the villages surveyed. The most important and popular method used for eggplant seed conservation was found to ex-situ conservation (91.77\%) without any chemical treatment. The seeds were often kept in loincloths (37.78\%), bottles or gourds (20.34\%) and bags (18.85\%) (Figure 4).

\section{Varietal preference criteria}

Fifteen preference criteria were identified in this study and classified as of agronomic (57.88\%), culinary (28.51\%) and economic (13.61\%) importance (Table 6). Farmers' preference criteria such as high productivity (14.96\%), earliness of accessions (12.18\%), resistance to the early falling of organs (7.14\%) and good conservation of fruit (7.45\%) were seen to be the most important agronomic traits. Eggplant farmers reported the indigenous knowledge of healers in Mono (20\%), Couffo (30\%) and Atacora (50\%) who use the fruits and leaves for medicinal purposes. Certain eggplant accessions thus appear to have medicinal proprieties of great importance for the treatment of healthcare problems. The high economic value of the fruits was found to be a common preference criterion to all the farmers in the study area.

\section{Constraints related to eggplant production in the study area}

Eggplant production is hindered by several constraints across the study area. Ten constraints were identified and prioritized (Table 7). These include the low commercial level of the fruits (37.06 \%), susceptibility to pests and diseases (18.01\%), lack of improved variety (11.85\%), low fruit storability (11.21\%). Soil poverty was found to be the main constraint in the center (14.05\%), whereas high susceptibility to soil moisture (14.66\%) was seen to be major abiotic constraint to the south Benin eggplant production. 


\section{Discussion}

Despite its low production level across all surveyed regions, Benin was seen to be an important refuge for scarlet eggplant diversity conservation. The higher levels of varietal diversity found in the north comparatively to the south and center Benin could have been correlated with human cultural diversity. Many territories exist at the periphery of northern Benin that borders Niger, Nigeria and Burkina-Faso with their ethnicity diverse. Human population structure occurring in this north part of Benin suggests a mosaic zone. As demonstrated by other studies, there is imperative interrelationship between cultural diversity and biodiversity $[40,41,20]$. This study showed greater diversity similarity within regions of the south, particularly in the departments of Mono and Couffo than within north and center regions. This finding suggests that there is possibly either a common ancestry or synonymy between eggplant accessions cultivated in south Benin due to the linguistic and geographic proximity of both departments and with Togo as well. Scarlet eggplant is broadly cultivated in Togo and there would be plant material exchanges with some mostly closed regions of Benin through informal seed system.

The method of consuming Solanum aethiopicum fruits (cooked or raw) does not require their prior blanching unlike that of traditional leafy vegetables. Blanching vegetables causes a significant loss of their soluble nutrients [42] but, it preserves their macronutrients better [43]. When fresh and eaten raw, their nutritional value is greater, but it is not always possible to consume them immediately (Boland, J., 2004). The high consumption of eggplant in the different recorded forms may be due to cultural preferences of the local communities [44].

This study revealed that none of the surveyed eggplant accessions was cultivated by several farmers and grown on large scale. The local farmers may have experienced a lot of difficulties of selling their products in the local markets at the highest rates as compared to other commercialized food products. A high proportion of Benin eggplant accessions have been almost abandoned and only remained as relict in some rural areas as a result of the fact that their food products would not be truly marketable. It is evident that eggplant accessions adopted by few farmers on small areas are in greater danger of extinction. These accessions deserve special attention and their discovery is crucial for preservation purposes. There is an urgent need for promoting their conservation and use in Benin [45]. Certain eggplant accessions were grown either by few farmers on large scale areas or by many farmers but on small scale. [45] pointed out that the lack of proper conservation strategies (in situ and ex situ) would expose them to possible genetic erosion or extinction. There are examples in which such conservation approaches have been applied to crops such as eggplant in Burkona Fasso [20], yam in Benin [29] and cassava in Congo [46].

Differences observed in the local names were the result of cultural differences between ethnic groups in the study area. Our finding is similar to that of [47] working on traditional leafy vegetables consumed in Benin. These authors found significant variation in the local leafy vegetables names across regions depending on ethnic groups. However, the current differences in the eggplant local names could not be only the fact of cultural but also genetic differences, related to farmers' preference criteria in function of types of morphotypes selected for cultivation. It seems likely that certain eggplant accessions, in particular those from the same region, although having different local names, are genetically very similar, giving way to nomenclature mistakes [20,48]. It is not obvious the total of 21 local names considered by farmers is truly 21 individual 
genotypes at genetic level due to and the synonymy problems. Genebanks must therefore use the traditional plant nomenclature with caution by trying first to confirm with genetic data in order for conservation to be properly achieved given that the same accession may have more than one local name differing in the complexity of languages used $[31,20,48]$. For example, there are many synonymies in the traditional nomenclature of cultivated plants in Benin. That is the case of Solanaceae family [49], cowpea [50] and traditional leafy vegetables [51]. But it is important to mention that this local nomenclature, although not very confident, allowed farmers to recognize and choose their accessions to grow [52].

Despite the significance of the local names of eggplant accessions, some practical aspects still remain to be clarified, namely the unexplained names and synonymy, mostly depending on the ethnicity of the study country $[51,52,53]$. As genetic diversity characterization was not an objective of this paper we suggest to further characterize these Benin scarlet eggplant accessions by using morphological and molecular markers. This would help to estimate more accurately the eggplant genetic diversity for its better conservation and use $[54,55]$.

Our study pointed out a rate of loss of varietal diversity relatively high in Benin scarlet eggplant. We assumed that the loss of diversity would be due to production constraints, such as poor sales of fruit, absence of local eggplant enhancement products, and absence of sales markets. This is in agreement with previous studies in cowpeas and Phaseolus, $[32,56]$. However, certain eggplant accessions have given way to some totems attached with it in south of Benin, especially in Adja culture. These totems are linked with some traditional religious concepts. For example, the Kumba groups (group 1: flat, highly lobed and round fruit eggplants) has been given deep and sacred meanings opposite to the deities of Adja people, which compel producers to gradually avoid growing, mostly for superstitious reasons. It is therefore evident that Benin indigenous cultures further contribute to the loss of eggplant varietal diversity. For example, many of the surveyed scarlet eggplant were restricted for growing in the south except Gilo group and Shum accessions. Similar results have been reported in Solanum macrocarpum (Gboma eggplant) [36] and Capsicum annuum [49].

Recorded data of agronomic importance provide possible indications that geophysical conditions could not be truly adapted to climate change with a major negative impact on Benin eggplant production. This may be one of the reasons for the difficulty in achieving better production of scarlet eggplant in certain localities when compared to others. When the same genotype is subjected to different environments, it can produce a wide range of phenotypes. As demonstrated in several studies, plant agronomic performance is a function of the genotype and environmental diversity [56]. As a consequence, further experiments at multiple locations are required to estimate the actual yield potential of the current eggplant accessions. Doing this, it will help to extend the scarlet eggplant accessions to large scale cultivation if proved to be agronomically well-performing. It is thus expected that the loss of varietal diversity slowdown in Benin. Similar approaches have been successfully used on plants such as eggplant $[9,1]$ and yam [57] across different countries and regions.

The cultivation practice of scarlet eggplants is similar to those of other leafy vegetables and fruits grown in the sub-region. The fight against pests consisted of the use of synthetic pesticides (chemical) and plant extracts as insect repellants. It is worrying that poorly or uninformed populations end up with toxic products that have harmful consequences for both humans and the environment. On the other hand, pesticide plants pose no threat to human health and the environment $[58,59]$. Under certain conditions, plant extracts can be 
comparable in effectiveness to conventional insecticides. Although this latter efficacy is not complete, it can nevertheless make it possible to keep the pest population below the harmful threshold and reduce the use of synthetic pesticides on vegetables [60].

Many constraints to eggplant production of Benin were reported in this study. Poor sales, the absence of upgrading products, the lack of high-performing accessions have been identified by farmers as major constraints they face. As a consequence many efforts are still needed for developing better productive eggplant accessions, resilient to many stress factors as possible including climate change and variability, diseases (viral and fungal), pests and poor soil fertility [46,33]. The eggplant susceptibility to the soil moisture that we reported in southern Benin would result from the negative effect of rivers that, during floods, threaten the survival of the eggplant accessions by destroying their natural habit. It causes root rot of the plants which resulted in premature falling of flowers and fruits off plants.

In any participatory agronomic study, several criteria determine the farmers' choice of plants to grow. Studies by [61] and [62] strongly recommended breeding for varieties that are suitable for local environmental conditions and production systems, with respect for preference criteria of the target communities. The farmers' preference criteria that we found should receive greater attention in our national eggplant breeding program with focus on their socioeconomic needs.

\section{Conclusion}

This study carried out showed that Benin eggplant production still remains traditional and limited to a few rural farmers. The varietal inventory revealed the existence of a moderate varietal diversity level, varying from one region to another. Farmers applied several selection criteria mostly related to agronomic and economic traits. In addition, eggplant production was affected by several constraints across the study area. However, we suspected certain accessions to be promising for good agronomic performance. We need to confirm this through agro-morphological and molecular characterization.

\section{Abbreviations}

BIORAVE: Biotechnology, Genetic Resources and Plant and Animal Breeding;

IPGRI : International Plant Genetic Research Institute.

\section{Declarations}

\section{Acknowledgments}

We thank the sarclet farmers for their active collaboration in this study. This work was funded by BIORAVE for the thesis of Scholastique Aguessy.

\section{Ethics approval and consent to participate}

No ethical approval was needed for this study. Prior to data collection, participants gave 
oral consent to participate in the study.

\section{Consent for publication}

Not applicable

\section{Competing interests}

The authors declare that they have no competing interests.

\section{Funding}

This work was funded by BIORAVE for the thesis of Scholastique Aguessy.

\section{Availability of data and materials}

Data generated during this study are available from the corresponding author.

\section{Authors' contributions}

SA, RI, AD, YLEL, OIY, AG and AD participated in the study design; they analyzed and

interpreted the data and drafted the manuscript. SA and RI carried out the field surveys. SA, RI, AD, YLEL, OIY, $A G, P A A, A D$ and $C A$ corrected the manuscript. All authors approved the final manuscript.

\section{References}

1. Sunseri F, Polignano GB, Alba V, Lotti C, Bisignano V, Mennella G (2010) Genetic diversity and characterization of African eggplant germplasm collection. Afr J Plant Sci. 4 (7):231-

2. Gramazio P, Blasnca J, Ziarsolo P, Herraiz FJ, Plazas M, Prohens J and Vilanova S (2016) Transcriptome analysis and molecular marker discovery in Solanum incanum and aethiopicum, two close relatives of the common eggplant (Solanum melongena) with interest for breeding. BMC Genom 17-300

3. FAO \& UNICEF (2018) WFP and WHO: The State of Food Security and Nutrition in the World 2018. Building climate resilience for food security and nutrition, 200.

4. Chinedu SN, Olasumbo AC, Eboji OK, Emiloju OC, Arinola OK \& Dania DI (2011) Proximate and Phytochemical analyses of Solanum aethiopicum and Solanum macrocarpon L. Fruits. Res J Chem Sci, 1(3):63-71

5. Nimenibo U \& Omotayo R (2019) Comparative Proximate, Mineral and Vitamin Composition of Solanum aethiopicum and Solanum melongena. NISEB Journal, 17(3).

6. Lim TK (2013) Solanum aethiopicum. In: Edible Medicinal And Non-Medicinal Plants. Springer, Dordrecht, 56-78

7. Ekweogu CN, Ude VC, Nwankpa P (2019) Ameliorative effect of aqueous leaf extract of Solanum aethiopicum on phenylhydrazine-induced anaemia and toxicity in rats. Toxicol Res. https://doi.org/10.1007/s43188-019-00021-5

8. White J (2010) Garden egg as solution to obesity and blindess. http://discussions.ghanaweb.com. 
9. Okon UE, Enete AA \& Bassey NE (2010) Technical efficiency and its determinants in Garden Egg (Solanum) production. Uyo Metropolis, Akwalbom State, Nigeria. Field Action Sci Rep, Special Issues (1)55

10. Denkyirah EK (2013) Variation in floral morphology, fruit set and seed quality of garden egg (Solanum aethiopicum vargilo) germplasm in Ghana. Doctoral dissertation, University of Ghana). ugspace.ug.edu.gh 1-26.

11. Taher D, Mohamed Rakha, Srinivasan Ramasamy, Svein Solberg and Roland Schafleitner (2019) Sources of Resistance for Two-spotted Spider Mite (Tetranychus urticae) in Scarlet (Solanum aethiopicum) and Gboma (S. macrocarpon L.) Eggplant Germplasms. Hortscience 54 (2):240-245.

12. Toppino L, Vale G, Rotino GL (2008) Inheritance of Fusarium wilt resistance introgressed from Solanum aethiopicum Gilo and Aculeatum groups into cultivated eggplant ( melongena) and development of associated PCR-based markers. Mol. Breed. 2008, 22, 237-250.

13. Lester RN \& Daunay MC (2003) Diversity of African vegetable Solanum species and its implications for a better understanding of plant domestication. Schriften zu Genetischen Ressourcen, 22, 137-152.

14. Horna D, Timpo S and Gruère G (2007) Marketing underutilized crops: the case of the african garden egg (Solanum aethiopicum) in Ghana. Global Facilitation Unit for Underutilized Species (GFU) 1-45.

15. Achigan-Dako EG, Pasquini MW, Assogba-Komlan F, N’danikou S, Yédomonhan H, Dansi A, Ambrose-Oji B (2010) Traditional vegetables in Benin. Institut National des Recherches Agricoles du Bénin. Imprimeries du CENAP, Cotonou N 4524., ISBN 978-99919-334-4-3, 1-282

16. Gruère GP (2006) An analysis of trade related international regulations of genetically modified food and their effects on developing countries (No. 147). Intl Food Policy Res Inst.

17. Padulosi S, Phrang R, Rosado-May FJ (2019) Soutenir une agriculture basée sur la nutrition grâce aux espèces négligées et sous-utilisées: Cadre opérationnel. Rome (Italie): Bioversity International et FIDA 48 p. ISBN: 978-92-9255-132-2 https://hdl.handle.net/10568/102463

18. Adango E, Onzo A, Hanna R Atachi P, Braima J (2006) Inventaire de la faune des acariens sur Amaranthus cruentus (Amaranthaceae), Solanum macrocarpon et Solanum aethiopicum (Solanaceae) dans le Sud Bénin. Int J Trop Insect Sci 26, 155-165.

19. Adeniji OT and Aloyce A (2012) Farmer's Knowledge of Horticultural Traits and Participatory Selection of African Eggplant Accessions (Solanum aethiopicum) in Tanzania. Tropicultura 30, 185-191.

20. Sawadogo Y, Ganaba S, Tindano E \& Some AN (2017) Characterization of the natural populations of a wild food legume, Senegalia macrostachya (Reichenb. ex DC. Kyal \& Boatwr) in the Northern Sudanian of Burkina Faso. Int J Biol Chem Sci 11(5), 2408-2420.

21. Ibrar M, Hussain F, Sultan A (2007) Ethnobotanical Studies on Plant Resources of Ranyal Hills, Distric Sangla Pakistan. Pak J Bot 39 (2): 329-337.

22. Aho N, Aho S, Agbokou I, Kaffo BA, Seni S et Loconon DZ (2018) Introduction à la résilience aux changements climatiques en Afrique de l'Ouest : Répertoire des dates prédéterminées des saisons pluvieuses dans les villages et quartiers de ville du Bénin. Ministère de l'Energie, de l'Eau et des Mines PNUD Bénin, Cotonou.

23. World Population Prospects (2017) United Nations population estimates and projections. Accessed on October 27, 202 
24. Amadou Sanni M (2017) Langues parlées au sein du ménage et assimilation linguistique au Bénin. Cahiers québécois de démographie, 46(2), 219-239. https://doi.org/10.7202/1054053ar

25. Akoègninou A, van der Burg WJ, van der Maesen LJG, (2006) Flore Analytique du Bénin. Leinden, Backhuys, $1034 \mathrm{P}$.

26. Yabi FB, Lougbegnon TO et Codjia JTC (2017) Influences Des Zones Biogéographiques Sur La Diversité Avienne Des Galeries Forestières Au Bénin, Afrique De l'Ouest. Journal scientifique européen, ESJ, 13(6), 410. https://doi.org/10.19044/esj.2017.v13n6p410

27. Dansi A, Dantsey-Barry H, Dossou-Aminon I, Kpenu EK, Agré AP, Sunu YD \& Assogba P (2013) Varietal diversity and genetic erosion of cultivated yams (Dioscorea cayenensis Poir- rotundata Lam complex and D. alata L.) in Togo. Int J Biodivers Conserv 5(4), 223-239.

28. Onwubuya EA, Ajani EN, Ugbajah MO \& Nenna MG (2013) Using honey production for enhancing household income among rural communities of Nsukka Local Government Area of Enugu State, Nigeria. Int J Agric Res, 1(2), 17-23.

29. Loko YL, Dansi A, Linsoussi C, Assogba P, Dansi M, Vodouhè R. \& Sanni A (2013) Current status and spatial analysis of Guinea yam (Dioscorea cayenensis-D. rotundata Poir. complex) diversity in Benin. IRJAS, 3(7), 219-238.

30. Adoukonou-Sagbadja H, Dansi A, Vodouhè R \& Akpagana K (2006) Indigenous knowledge and traditional conservation of fonio millet (Digitaria exilis, Digitaria iburua) in Togo. Biodivers Conserv, 15(8), 2379-2395.

31. Dansi A, Adoukonou-Sagbadja H, Vodouhé R (2010) Diversity, conservation and related wild species of Fonio millet (Digitaria) in the north west of Benin. Genet Resour Crop Evol, 57: 827839.

32. Gbaguidi AA, Dansi A, Loko LY, Dansi M, Sanni A, (2013) Diversity and agronomic performances of the cowpea (Vigna unguiculata) landraces in Southern Benin. IRJAS 3(4):121-133.

33. Tumuhimbise R, Melis R, Shanahan P \& Kawuki R (2012) Farmers' perceptions on early storage root bulking in cassava (Manihot esculenta Crantz) in east and central Uganda and their implication for cassava breeding. World J Agric Sci Res, 8(4), 403-408.

34. Agre AP, Dansi A, Rabbi IY, Battacharjee R, Dansi M, Melaku G, Augusto B, Sanni A, Akouegninou A, Akpagana K (2015) Agromorphological Characterization of Elite Cassava (ManihotesculentaCrantz) Accessions Collected in Benin. J. Curr. Res. Biosci. Plant Biol, 2(2): 1-14.

35. IPGRI (1998) Descriptors for eggplants. IPGRI, Rome Italy.

36. Lohar DP, Kouassi HM, Nassa R, Yao K, Kouame K \& Biemi J (2018) Modélisation statistique des pluies maximales annuelles dans le District d'Abidjan (Sud de la Côte d'Ivoire). Des Sci. De L'Eau, 31(2), 147-160.

37. Maechler M, Bates D, Bolker B, Walker S, Christensen RHB, Singmann H \& Green P (2018) Package 'Ime4'. Version, 1, 17.

38. R Core Team R (2018) A Language and Environment for Statistical Computing; R Foundation for Statistical Computing: Vienna, Austria, 2018; Available online: https://www.R-project.org/.

39. Wonni I, Bourgou L, Zombre C, Sanga I, Zougrana S \& Ouedraogo L (2019) Incidence de la bactériose du cotonnier causée par Xanthomonas citri malvacearum sur les variétés conventionnelles cultivées au Burkina Faso. Afrique SCl, 15(4), 113-121. 
40. Ahmad I, Hussain M, Ahmad MSA, Hameed M (2008) Spatio-temporal effects on association of plant species in some valley of Pakistan. Pak. J. Bot. 40:1865-1876.

41. Ishtiaq M, Maqbool M \& Hussain T (2012) Interrelationship of cultural diversity and biodiversity and its impact on conservation. Pak J Botany, 44, 245-56.

42. Parkouda C, Ba/Hama F, Tenkouano A, Kamga R, Diawara B (2016) Légumes Traditionnels Africains: Guide de Bonnes Pratiques de Conservation et de Transformation / Traditional African Vegetables: Good Practices for Conservation and Transformation. AVRDC - The World Vegetable Center, Taiwan. Publication no. 16-798. $103 \mathrm{p}$.

43. Vodouhe SR, Dovoedo A, Anihouvi VB, Tossou RC (2013). Influence du mode de cuisson sur la valeur nutritionnelle de Solanum macrocarpum, Amaranthus hybriduset Ocimum gratissimum, trois légumes feuilles traditionnels acclimatés au Bénin. DOI: 4314/ijbcs.v6i5.3 Published 2013-02-05 Issue Vol. 6 No. 5

44. Kouassi A, N'gbesso FDPM, Fondio L \& Djidji HA (2016) Etude de la diversité intra et interspécifique des caractères phénotypiques chez deux espèces d'aubergines africaines: Solanum macrocarpon (L.) et Solanum dasyphyllum (L.). J Biol Chem Sci 10(4), 1793-1804.

45. Jarvis S \& Odlin T (2000) Morphological type, spatial reference, and language transfer. Studies in second language acquisition, 22 (4), 535-556.

46. Kombo GR, Dansi A, Loko LY, Orkwor GC, Vodouhè R, Assogba P \& Magema JM (2012) Diversity of cassava (Manihot esculenta Crantz) cultivars and its management in the department of Bouenza in the Republic of Congo. Genet Resour Crop Evol, 59(8), 1789-1803.

47. Adjatin A, Dansi-Anagonou A, Badoussi E, Loko YL, Dansi M, Azookpota P, Gbaguidi F, Ahissou H, Akoègninou A, Akpagana $K$ and Sanni A (2013) Phytochemical screening and toxicity studies of Crassocephalum rubens (Juss. Ex Jacq), S. Moore and Crassocephalum crepidioides (Benth.) S. Moore consumed as vegetable in Benin. Int J Curr Microbiol Appl Sci pp. 1-13.

48. Wembou EP, Odah K, Dansi A, Kabiezim E, Tozo K, Akpagana K (2017) Diversité variétale et conservation des ignames cultivées (Dioscorea cayenensis, Dioscorea rotundata et Dioscorea alata) dans la région de la Kara (Togo). African J Food Agric Nutr Dev, 5 (4):391-399

49. Orobiyi A, Dansi A, Assogba P, Loko LY, Dansi M, Vodouhè R, Akouègninou A, Sanni $A(2013)$ Chili (Capsicum annuum) in southern Benin: production constraints, varietal diversity, preference criteria and participatory evaluation. Int Res J Agricult Sci Soil Sci, 3(4): 107120.

50. Gbaguidi AA, Assogba P, Dansi M, Yedomonhan H et Dansi A (2015) Caractérisation agromorphologique des variétés de niébé cultivées au Bénin. Int J Biol Chem Sci, 9(2): 1050-1066

51. Adjatin A, Dansi A, Eze CS, Assogba P, Dossou-Aminon I, Akpagana K, Akoègninou A. and Sanni A (2012) Ethnobotanical investigation and diversity of Gbolo and (Crassocephalum rubens (Juss. ex Jacq.) $S$. Moore and crepidioides (Benth.) S. Moore), a traditional leafy vegetable under domestication in Benin. Genet Ressource Crop 59(8):1867-1881.

52. Gnawe M, Yedomonhan H, AdomouAC,Houenon H, Dansi A, Akoegninou A (2016) Nomenclature vernaculaire et diversité des variétés locales des gombos (Abelmoschus spp.) cultivées au Bénin. J appl biosci 106:10224-10235

53. Hessavi M, Bénédicte F, Adjatin A, Ayena A, Agassounon D, Tchibozo M (2019) Investigation ethnobotanique, profil phytochimique et cytotoxicité de Bambusa vulgaris Ex J.C. Wendl. (Poacee), une 
espèce à usages multiples et sous-utilisée au Bénin. J Anim Plant Sci, Vol.39, Issue 2: 6435-6453, http://www.m.elewa.org/JAPS; ISSN 2071-7024.

54. Lekkas E, Andreadakis E, Alexoudi V, Kapourani E \& Kostaki I (2011) The Tohoku Japan earthquake (March 11, 2011) tsunami impact on structures and infrastructure. In Environmental Geosciences and Engineering Survey for Territory Protection and Population Safety (EngeoPro) International conference, Moscow(pp. 97-103).

55. Mezette TF, Blumer CG \& Veasey EA (2013) Morphological and molecular diversity among cassava genotypes. Agropecu. Bras, 48(5), 510-518.

56. Missihoun AA, Houssou MW, Montcho D, Agbo RI, Sedah P, Agbangla C (2017) Diversité variétale et gestion paysanne des haricots cultivés du genre Phaseolus cultivés au Centre et au Sud Bénin (en Afrique de l'Ouest). J Appl Biosci 118: 11817-11828 ISSN 1997-5902.

57. Mondedji AD, Nyamador WS, Amevoin K, Adéoti R, Abbévi AG, Koffivi KG et Glitho IA (2015) Analyse de quelques aspects du système de production légumière et perception des producteurs de l'utilisation d'extraits botaniques dans la gestion des insectes ravageurs des cultures maraîchères au Sud du Togo. Int J Biol Chem Sci, 9(1): 98-107.

58. Sujayanand GK, Sharma RK, Shankarganesh K, Saha S \& Tomar RS (2015) Crop diversification for sustainable insect pest management in eggplant (Solanales: Solanaceae). Fla entomol, 305-314.

59. Anjarwalla P, Belmain S, Sola P, Jamnadass R, Stevenson PC (2016) Guide des plantes pesticides. World Agroforestry Centre (ICRAF), Nairobi, Kenya.

60. Yarou BB, Silvie P, Assogba-Komlan F, Mensah A, Alabi T, Verheggen F, Francis F (2017) Plantes pesticides et protection des cultures maraîchères en Afrique de l'Ouest (synthèse bibliographique). Biotechnol Agron Soc Environ 21(4), 288-304. https://doi.org/10.25518/1780-4507.16175

61. Franck JI, Franklin RJ \& Haer FC (2001) S. Patent No. 6,327,491. Washington, DC: U.S. Patent and Trademark Office.

62. Mohammed S \& Nadkarni S (2011) Temporal diversity and team performance: The moderating role of team temporal leadership. Acad Manage J, 54(3), 489-508.

\section{Tables}

\section{Table 1.}




\begin{tabular}{|c|c|c|c|c|c|}
\hline \multirow[t]{2}{*}{ Parameters } & \multirow[t]{2}{*}{ Levels } & \multicolumn{4}{|c|}{ Percentage of responses (\%) } \\
\hline & & South & Centre & North & Study area (\%) \\
\hline \multirow[t]{2}{*}{ Genders } & Men & 9.54 & 7.67 & 10.95 & 28.16 \\
\hline & Women & 24.65 & 20.44 & 26.75 & 71.84 \\
\hline \multirow[t]{4}{*}{ Education } & Non educated & 26.54 & 18.85 & 21.34 & 66.73 \\
\hline & Primary level & 6.35 & 6.85 & 7.64 & 20.84 \\
\hline & Secondary & 2.25 & 4.75 & 3.56 & 10.56 \\
\hline & University & 1.02 & 0.35 & 0.5 & 1.87 \\
\hline \multirow[t]{4}{*}{ Religions } & Islamic & 26.45 & 35.17 & 53.51 & 38.38 \\
\hline & Christians & 46.45 & 39.59 & 24.78 & 36.94 \\
\hline & Tradition & 21.55 & 20.56 & 19.44 & 20.52 \\
\hline & Others/None & 5.55 & 4.68 & 2.27 & 4.16 \\
\hline \multirow[t]{4}{*}{ Age } & $<30$ years & 8.33 & 8.87 & 10.56 & 9.25 \\
\hline & $30-50$ years & 36.71 & 38.87 & 38.76 & 38.11 \\
\hline & $51-70$ years & 49.55 & 47.59 & 43.15 & 46.76 \\
\hline & $>70$ years & 5.41 & 4.67 & 7.53 & 5.88 \\
\hline \multirow[t]{4}{*}{ Experiences } & $<5$ years & 12.33 & 11.76 & 10.65 & 11.58 \\
\hline & 6- 10 years & 33.65 & 28.77 & 31.96 & 31.46 \\
\hline & $11-20$ years & 42.32 & 47.88 & 43.33 & 44.51 \\
\hline & $>20$ years & 11.7 & 11.59 & 14.06 & 12.45 \\
\hline \multirow[t]{5}{*}{ Activities } & Levels & \multicolumn{4}{|c|}{ Percentage of responses (\%) } \\
\hline & & Principal & Secondary & Tertiary & Study area \\
\hline & Agriculture & 68.65 & 39.44 & 31.76 & 46.62 \\
\hline & Artisans & 40.25 & 27.11 & 1.21 & 22.86 \\
\hline & Traders & 38.96 & 27.87 & 24.75 & 30.52 \\
\hline
\end{tabular}

Table 2. 


\begin{tabular}{|c|c|c|}
\hline $\mathrm{N}^{\mathrm{O}}$ & $\begin{array}{l}\text { Local name and } \\
\text { Languages }\end{array}$ & Distribution through villages \\
\hline 1 & Gboyi (Adja) & $\begin{array}{l}\text { Azovè (+-); Dékpo (-); Kissamey (+-), Banigbé (+-), Yovogahoué (+-), } \\
\text { Edaguizohoué(+-), Zaffi (-), Tchikpé (+-), Lokogba (+-) }\end{array}$ \\
\hline 2 & $\begin{array}{l}\text { Gbitchan } \\
\text { (Kotafon, Tala) }\end{array}$ & Monoto (++), Atchannou (+-) \\
\hline 3 & $\begin{array}{l}\text { Agbissan } \\
\text { (Kotafon, Fon, } \\
\text { Mahi, Goun) }\end{array}$ & Monoto (++); Doukonta (++), Ahondomey (-); Bamè (-) \\
\hline 4 & Egboyi (Adja) & $\begin{array}{l}\text { Dékpo (-); Kissamey (+-), Banigbé(+-), Yovogahoué (+-), Edaguizohoué(+-), } \\
\text { Zaffi (-), Tchikpé (+-), Lokogba (+-) }\end{array}$ \\
\hline 5 & $\begin{array}{l}\text { Gbitchan lobo } \\
\text { (Tala) }\end{array}$ & Atchannou (-) \\
\hline 6 & $\begin{array}{l}\text { Gbitchangodo } \\
\text { (Tala) }\end{array}$ & Atchannou (-) \\
\hline 7 & $\begin{array}{l}\text { Gboyigouroto } \\
\text { (Adja) }\end{array}$ & $\begin{array}{l}\text { Azovè (+-); Dékpo (-); Kissamey (+-), Banigbé (+-), Yovogahoué (+-), } \\
\text { Edaguizohoué(+-), Zaffi (-), Tchikpé (+-), Lokogba (+-), Kpétou (-) }\end{array}$ \\
\hline 8 & $\begin{array}{l}\text { Gboyilogboto } \\
\text { (Adja) }\end{array}$ & Tchikpé (+-), Doutou (-) \\
\hline 9 & $\begin{array}{l}\text { Agbitchan } \\
\text { (Watchi, Mahi) }\end{array}$ & Dédékpoè (-) \\
\hline 10 & $\begin{array}{l}\text { Ikan (Yorouba, } \\
\text { Nagot, Holli, } \\
\text { Idaatcha, Ifè, } \\
\text { Tchabè) }\end{array}$ & $\begin{array}{l}\text { Oko-Akaré (-), Sodji(+-), Ogando (-), Adja-ouèrè (+-), Itchagba-holi (-), Idigny } \\
(+-) \text {, Iwoyé }(++) \text {, Illara (++), Ayékou (-), Odomèta (-), Oko-owo }(-) \text {, Ouihi }(-) \text {, } \\
\text { Magoumi (-), Gouka (+-), Awaya (+-), Odo-ôtchèrè (+-) }\end{array}$ \\
\hline 11 & $\begin{array}{l}\text { Ikanrodo } \\
\text { (Yorouba, Nagot, } \\
\text { Holli) }\end{array}$ & $\begin{array}{l}\text { Aguidi (+-), Igolo (-), Oko-Akaré (-), Sodji (+-), Ogando (-), Adja-ouèrè (+-), Iwoyé } \\
(++) \text {, Illara }(++)\end{array}$ \\
\hline 12 & $\begin{array}{l}\text { Ikangougou } \\
\text { (Nagot, } \\
\text { Holi,Yorouba) }\end{array}$ & Iwoyé (++), Illara (++), Ayékou (-), Odomèta (-), Oko-owo (-) \\
\hline 13 & Kélé (Lokpa) & $\begin{array}{l}\text { Pénélan (-), Kandi (-); Gouroubéri (+-); Yanro-Bariba (-); Djagbalo (-); Sanson (- } \\
- \text {-); Perporiakou (-); Pérégourou (+-), N'dahonta (-) }\end{array}$ \\
\hline 14 & $\begin{array}{l}\text { Kpaanoulaka } \\
\text { (Lokpa) }\end{array}$ & $\begin{array}{l}\text { M'bayakou (-); Pénélan (-), Kandi (-); Gouroubéri (+-); Yanro-Bariba (-); Founga } \\
(-) \text {; Djagbalo (-); Sanson (-); Perporiakou (-) }\end{array}$ \\
\hline 15 & Koklozingbo & Doukonta (++), Monoto (-) \\
\hline 16 & Sambini (Bariba) & $\begin{array}{l}\text { Djougou (++), Gambané (+-), Ouéké (-), Pabégou (-), Allédjo (-), Tomboutou (- } \\
- \text {-), Yanro-Bariba (-), Yarra (-), Sombékourou (-), Bariénou (-), Perporiakou (+-), } \\
\text { Kawado(-), Kassa (+-), Kolokondé(-), Malanville (+-) }\end{array}$ \\
\hline 17 & $\begin{array}{l}\text { Yètchanmiyé } \\
\text { (Ditamari) }\end{array}$ & N'dali (-) \\
\hline 18 & $\begin{array}{l}\text { Yèkan (Lokpa, } \\
\text { Ditamari) }\end{array}$ & N'dali (-), Tokotoko (-), Mallanville (-), Kpakpavissa (-), Kondé (+-) \\
\hline
\end{tabular}


19 Yèkan'tchantchayè Founga (-), N'dali (-), Tchanhounkossi (-) (Ditamari)

$\begin{array}{lll}20 & \text { Gabta (Dendi) } & \text { Gouroubéri (-); Akpadanou (-) } \\ 21 & \begin{array}{l}\text { Kaanan } \\ \text { (Gourmanché) }\end{array} & \text { Datori (-), Tanguiéta (+-), Dipoko (-), Cobly (+-) }\end{array}$

\section{Table 3.}

\begin{tabular}{|llllll|}
\hline Variables & Minimum & Maximum & Mean \pm SE & StDev & CV (\%) \\
\hline NTV & 1 & 3 & $2.02 \pm 0.05$ & 0.5131 & 25.38 \\
\hline M+S+ & 0 & 0 & - & - & - \\
\hline M+S- & 0 & 2 & $0.93 \pm 0.05$ & 0.44 & 47.06 \\
\hline M-S+ & 0 & 2 & $0.96 \pm 0.05$ & 0.47 & 48.80 \\
\hline M-S- & 0 & 2 & $0.96 \pm 0.05$ & 0.47 & 48.80 \\
\hline NVI & 0 & 1 & $0.04 \pm 0.02$ & 0.21 & 71.61 \\
\hline NVD & 0 & 2 & $0.52 \pm 0.06$ & 0.54 & 74.32 \\
\hline TPDV (\%) & 0 & 66.67 & $23.55 \pm 2.54$ & 24.35 & 73.41 \\
\hline
\end{tabular}

NTV: Total number of accessions per village; $M+S+$ : Number of accessions cultivated by many household on large area; M+S-: Many household and small area; M-S+: Few household and large area; M-S-: Few household small area; NVI: Number of new introduced accessions; NVD: Number of accessions lost; TPDV: Diversity lost index, SE: Standard error, StDev: Standard deviation, CV: Coefficient of variation.

\section{Table 4.}




\begin{tabular}{|lllllll|}
\hline $\mathbf{N}^{\bullet}$ & Departments & NV & H (bits) & NMiC & NMaC & Mean \\
\hline 1 & Couffo & 12 & 3.65 & 1 & 3 & $2.02 \pm 0.85^{\mathrm{a}}$ \\
\hline 2 & Collines & 11 & 3.47 & 1 & 2 & $2.05 \pm 0.23^{\mathrm{a}}$ \\
\hline 3 & Borgou & 10 & 2.61 & 1 & 2 & $2.01 \pm 0.43^{\mathrm{b}}$ \\
\hline 4 & Alibori & 9 & 3.21 & 1 & 3 & $2.00 \pm 0.84^{\mathrm{a}}$ \\
\hline 5 & Atacora & 9 & 3.88 & 1 & 4 & $3.01 \pm 0.95^{\mathrm{a}}$ \\
\hline 6 & Donga & 9 & 2.50 & 1 & 2 & $2.00 \pm 0.45^{\mathrm{b}}$ \\
\hline 7 & Mono & 10 & 3.50 & 1 & 3 & $2.26 \pm 0.93^{\mathrm{a}}$ \\
\hline 8 & Ouémé & 5 & 1.22 & 1 & 2 & $1.01 \pm 0.41^{\mathrm{c}}$ \\
\hline 9 & Plateau & 10 & 3.35 & 1 & 2 & $2.03 \pm 0.88^{\mathrm{a}}$ \\
\hline 10 & Zou & 7 & 1.33 & 1 & 1 & $1.02 \pm 0.63^{\mathrm{c}}$ \\
\hline Study area & $\mathbf{9 2}$ & $\mathbf{2 . 6 9}$ & $\mathbf{1}$ & $\mathbf{2}$ & $\mathbf{2 . 0 2 \pm 0 . 3 6}$ \\
\hline
\end{tabular}

Legends :NV: number of villages surveyed, H: Diversity index, NMic: Minimum number of accession per village, NMaC: Maximum number of accessions per village

Table 5. 


\begin{tabular}{|c|c|c|c|c|c|c|c|c|c|}
\hline \multicolumn{2}{|c|}{ Pest and Diseases } & \multicolumn{2}{|c|}{ SOUTH } & \multicolumn{2}{|c|}{ CENTRE } & \multicolumn{2}{|c|}{ NORTH } & \multirow{2}{*}{\multicolumn{2}{|c|}{$\begin{array}{l}\text { Study area } \\
\text { (\%) }\end{array}$}} \\
\hline \multirow[t]{2}{*}{ Categories } & \multirow{2}{*}{$\begin{array}{l}\text { Percentage (\%) / } \\
\text { Modalities }\end{array}$} & & & & & & & & \\
\hline & & Inc & MS & Inc & MS & Inc & MS & Inc & MS \\
\hline $\begin{array}{l}\text { Gall } \\
\text { nematodes }\end{array}$ & 10 & 50 & 1.4 & 10 & 0.7 & 50 & 1.3 & 36.67 & 1.13 \\
\hline $\begin{array}{l}\text { Dry crown } \\
\text { rot }\end{array}$ & 40 & 30 & 1.2 & 10 & 1 & 50 & 1.3 & 30.00 & 1.17 \\
\hline $\begin{array}{l}\text { Bacterial } \\
\text { wilt }\end{array}$ & 50 & 30 & 1 & 20 & 1 & 40 & 1 & 30.00 & 1.00 \\
\hline Mean & 55.00 & 36.67 & 1.20 & 13.33 & 0.90 & 46.67 & 1.2 & 32.22 & 1.10 \\
\hline Caterpillars* & 28 & 50 & 1.2 & 10 & 1 & 30 & 1.3 & 30.00 & 1.17 \\
\hline $\begin{array}{l}\text { Flower and } \\
\text { fruit borers* }\end{array}$ & 32 & 40 & 1.3 & 30 & 1.1 & 40 & 1.3 & 36.67 & 1.23 \\
\hline $\begin{array}{l}\text { Stinking } \\
\text { locusts* }\end{array}$ & 40 & 30 & 1.1 & 20 & 1 & 30 & 1.2 & 26.67 & 1.10 \\
\hline Mean & 45.00 & 40.00 & 1.20 & 20.00 & 1.03 & 33.33 & 1.27 & 31.11 & 1.17 \\
\hline \multicolumn{2}{|c|}{ Local means of treatment } & \multirow{2}{*}{\multicolumn{2}{|c|}{25.05}} & \multirow{2}{*}{\multicolumn{2}{|c|}{0}} & \multirow{2}{*}{\multicolumn{2}{|c|}{21.16}} & \multirow{2}{*}{\multicolumn{2}{|c|}{46.21}} \\
\hline \multirow[t]{3}{*}{$\begin{array}{l}\text { Leaves } \\
\text { extracts }\end{array}$} & $\begin{array}{l}\text { Leaves extracts of } A \text {. } \\
\text { Indica }\end{array}$ & & & & & & & & \\
\hline & $\begin{array}{l}\text { Leaves } \\
\text { extractsof H.suaveolens }\end{array}$ & 22.16 & & 13.8 & & 22.25 & & 58.21 & \\
\hline & Mean & 23.605 & & 6.9 & & 21.70 & & 52.21 & \\
\hline Wood ashes & Wood ashes & 11.16 & & 16.23 & & 6.04 & & 33.43 & \\
\hline $\begin{array}{l}\text { Local } \\
\text { fences }\end{array}$ & Local fences & 5.34 & & 4.26 & & 4.76 & & 14.36 & \\
\hline
\end{tabular}

Legends:Inc: Incidence in percentage (\%), MS: Mean severity, *Pest

Table 6. 


\begin{tabular}{|c|c|c|c|c|c|}
\hline \multirow[t]{2}{*}{ Categories } & \multirow[t]{2}{*}{ Criteria for preference } & \multirow{2}{*}{$\begin{array}{l}\text { Study area } \\
(\%)\end{array}$} & \multicolumn{3}{|c|}{ Percentage per regions (\%) } \\
\hline & & & South & Centre & North \\
\hline \multirow[t]{11}{*}{ Agronomic (58.17\%) } & High productivity & 14.96 & 15.28 & 16.16 & 13.43 \\
\hline & Earliness of accession & 12.18 & 11.17 & 13.12 & 12.25 \\
\hline & Resistance to flowers and fruits bores & 7.14 & 2.92 & 4.22 & 14.28 \\
\hline & Good fruits storability & 7.45 & 8.21 & 11.67 & 2.46 \\
\hline & Adaptability to several types of soils & 4.87 & 3.37 & 5.01 & 6.24 \\
\hline & Resistance to diseases & 3.66 & 3.49 & 4.34 & 3.15 \\
\hline & Tolerance to drought & 2.66 & 2.89 & 2.43 & - \\
\hline & Tolerance to weeds & 2.38 & 1.37 & 2.33 & 3.25 \\
\hline & Tolerance to poor soils & 2.58 & 3.98 & 1.32 & 2.45 \\
\hline & Easiness of fruit harvest & 1.96 & 2.5 & 1.21 & - \\
\hline & Total & 57.88 & 55.18 & 61.81 & 57.51 \\
\hline \multirow{5}{*}{$\begin{array}{l}\text { Culinary } \\
(28.22 \%)\end{array}$} & Good taste & 11.97 & 12.23 & 11.43 & 12.25 \\
\hline & Good bitterness rate & 6.73 & 5.65 & 4.34 & 10.21 \\
\hline & Leafy vegetable ability & 5.43 & 2.37 & 8 & 5.31 \\
\hline & Good culinary quality & 4.38 & 6.54 & 2.08 & 4.25 \\
\hline & Total & 28.51 & 26.79 & 25.85 & 32.02 \\
\hline Economic (10.47) & High market value & 13.61 & 18.03 & 12.34 & 10.47 \\
\hline
\end{tabular}

Table 7. 


\begin{tabular}{|c|c|c|c|c|c|}
\hline \multirow[t]{3}{*}{$\mathbf{N}^{\circ}$} & \multirow[t]{3}{*}{ Constraints of production } & \multicolumn{4}{|c|}{ Percentage of responses (\%) } \\
\hline & & \multicolumn{3}{|c|}{ Regions } & \multirow[t]{2}{*}{ Study area } \\
\hline & & South & Centre & North & \\
\hline 1 & Low commercial level & 28.55 & 37.06 & 22.26 & 29.29 \\
\hline 6 & Susceptibility to pests and diseases & 18.49 & 17.02 & 18.53 & 18.01 \\
\hline 4 & Soil poverty & 8.17 & 14.05 & 13.42 & 11.88 \\
\hline 2 & Lack of improved variety & 12.01 & 11.02 & 12.51 & 11.85 \\
\hline 3 & Low fruit storability & 10.61 & 11.23 & 11.78 & 11.21 \\
\hline 5 & Susceptibility to high soil moisture & 14.66 & - & 13.39 & 9.35 \\
\hline 7 & Drought & 7.51 & 9.62 & 8.11 & 8.41 \\
\hline
\end{tabular}

\section{Figures}




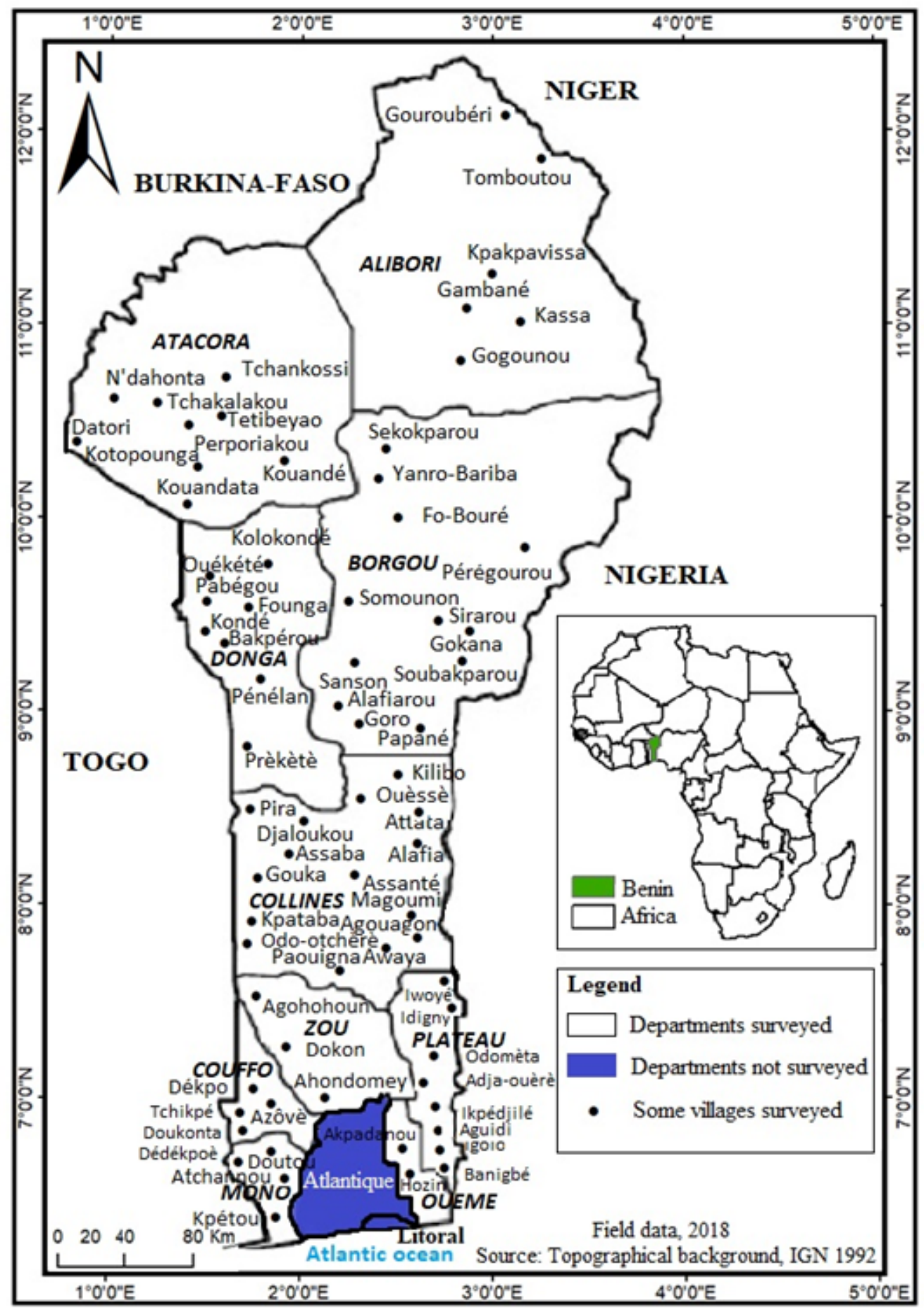

Figure 1

Ninety-two (92) villages (Table 1; Figure 1) located in diverse agro-ecological (humid, semi-arid, arid) and ethnic zones across 10 administrative departments (Alibori, Atacora, Borgou, Collines, Couffo, Donga, Mono, Ouémé, Plateau, Zou) were surveyed in this study, which were estimated to cover the whole country in order to establish an exhaustive collection. Villages to be surveyed within departments were indicated by the officers of the national extension services of the ministry of agriculture operating in the departments. Prior to the survey, major markets of each department were also visited to collect from the scarlet eggplant sellers some indications about the potential villages to consider. 15 to 39 villages were considered per department. The designations employed and the presentation of the material on this map do not imply the expression of any 
opinion whatsoever on the part of Research Square concerning the legal status of any country, territory, city or area or of its authorities, or concerning the delimitation of its frontiers or boundaries. This map has been provided by the authors.

\section{Cluster Dendrogram}

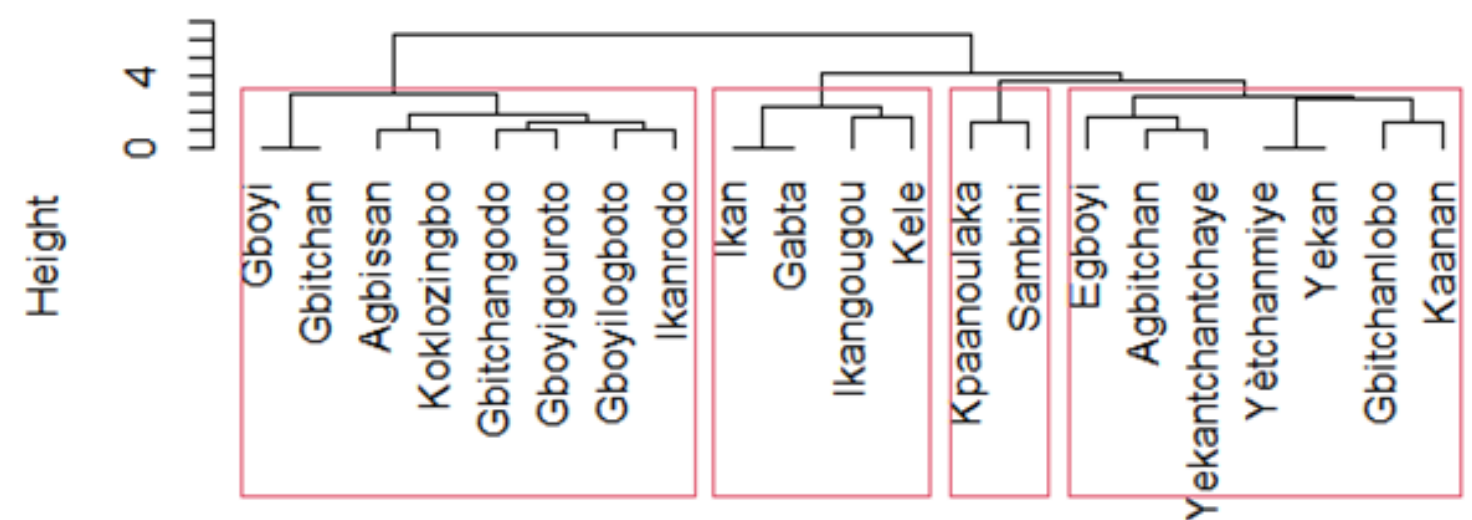

dist(clustmorpho)

hclust (*, "ward.D")

\section{Figure 2}

In the study area, the scarlet eggplant showed a low varietal diversity ranging from 1 to 3 accessions per village (Table 3). An average of two scarlet eggplant accessions was recorded in each surveyed village. It appeared that no variety was produced by many households and on large scale cultivation (Table 3) except Gboyigouroto who truly spread the eggplant production in Yovogahoué village located in southern Benin. The Shannon-Weaver diversity index calculated $(H)$ varied from low to medium varietal diversity ranging from 1.22 to 3.88 scores across Benin villages (Table 4). The scarlet eggplant diversity was found to be very low in Zou and Ouémé departments, low in Borgou and Donga and medium in certain regions of Atacora, Couffo, Mono, Plateau and Collines (Table 4). Four morphotypes were identified based on the different morphological characteristics of eggplants accessions listed by farmers (color, shape, size, taste of the fruit, number of lobes) (Figure 2 and 3).All these four morphotypes was found in northern Benin, whereas only two morphotypes occur in the central and southern part of the country. 


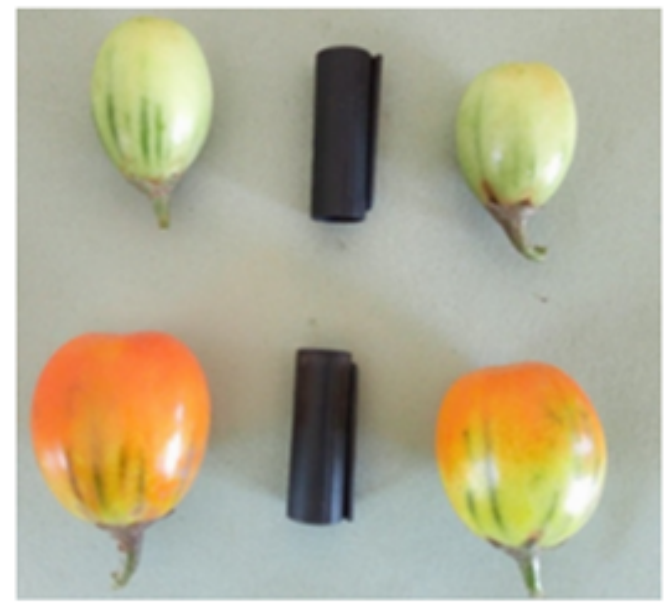

Group 1: (Sud, Centre, Nord)

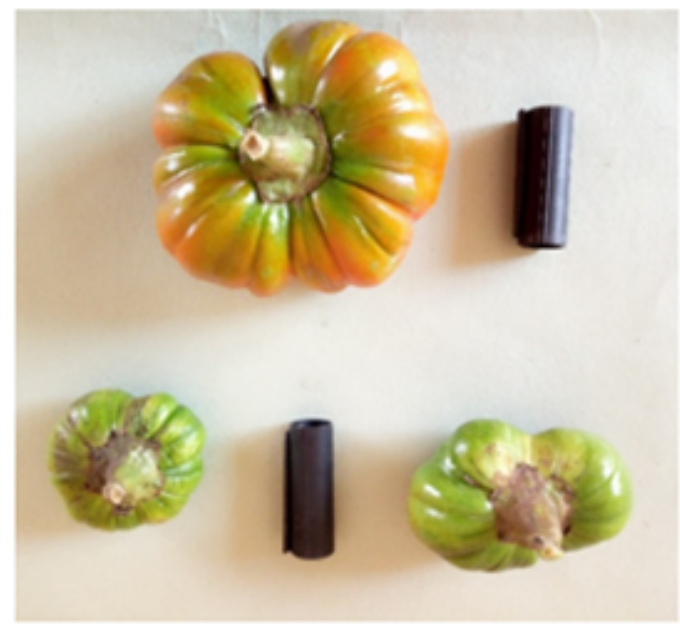

Group 3: (Centre, Nord)

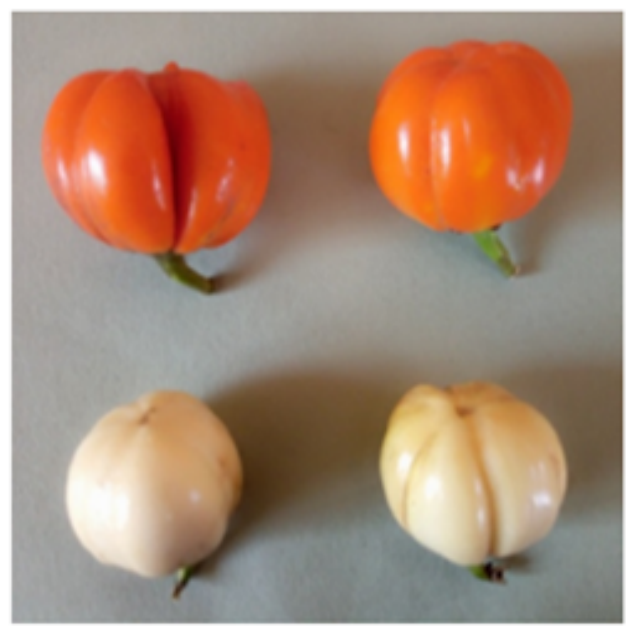

Group 2: (Centre, Nord)

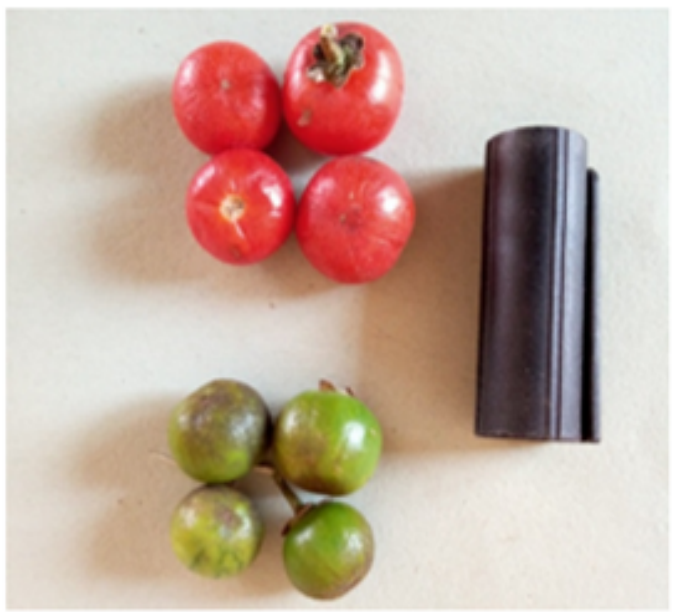

Group 4: (Sud, Nord)

\section{Figure 3}

In the study area, the scarlet eggplant showed a low varietal diversity ranging from 1 to 3 accessions per village (Table 3). An average of two scarlet eggplant accessions was recorded in each surveyed village. It appeared that no variety was produced by many households and on large scale cultivation (Table 3) except Gboyigouroto who truly spread the eggplant production in Yovogahoué village located in southern Benin. The Shannon-Weaver diversity index calculated $(\mathrm{H})$ varied from low to medium varietal diversity ranging from 1.22 to 3.88 scores across Benin villages (Table 4). The scarlet eggplant diversity was found to be very low in Zou and Ouémé departments, low in Borgou and Donga and medium in certain regions of Atacora, Couffo, Mono, Plateau and Collines (Table 4). Four morphotypes were identified based on the different morphological characteristics of eggplants accessions listed by farmers (color, shape, size, taste of the fruit, number of lobes) (Figure 2 and 3).All these four morphotypes was found in northern Benin, whereas only two morphotypes occur in the central and southern part of the country. 

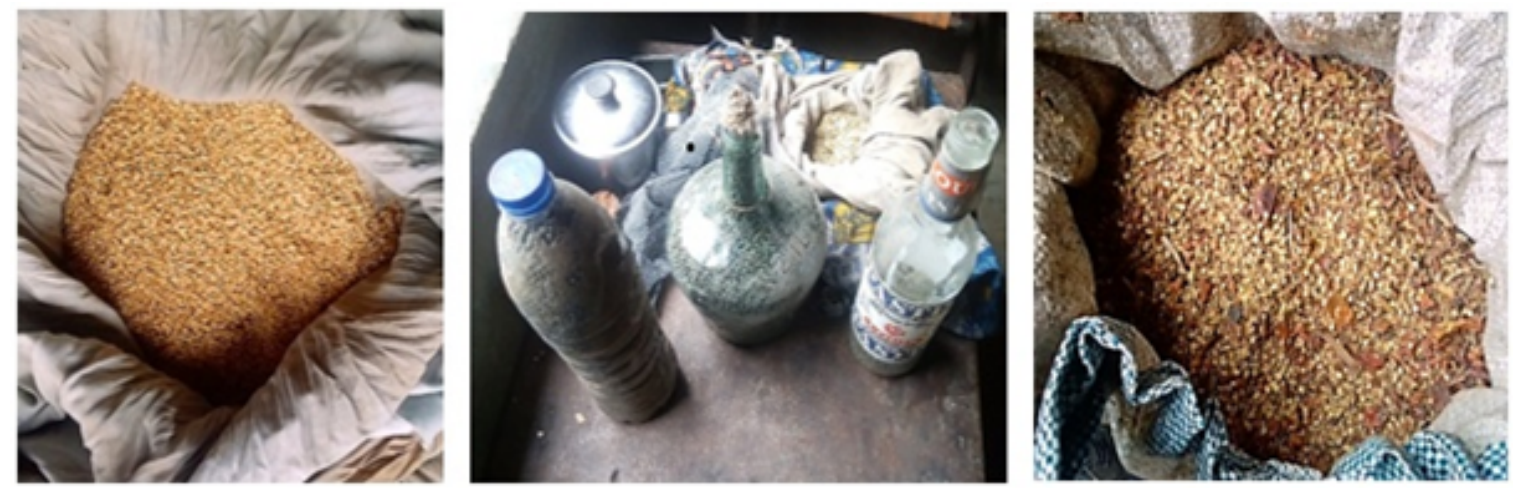

\section{Figure 4}

Self-production (crop retention) of eggplant seeds was the main mode of seed supply adopted by majority of Benin farmers (82.23\%). The choice of seed retained for the next production season was mainly based on the size $(33.22 \%)$ and shape (24.65\%) of eggplant fruits. Farmers (42.13\%) also make selection of good quality first fruits. After physiological maturity of these fruits they dedicate them to sowing the next eggplant generations. There was no relevant information on the acquisition of seeds by inheritance (7.09\%), donation (6.32\%), purchase (3.11\%) and exchange (1.25\%) in the villages surveyed. The most important and popular method used for eggplant seed conservation was found to ex-situ conservation (91.77\%) without any chemical treatment. The seeds were often kept in loincloths $(37.78 \%)$, bottles or gourds $(20.34 \%)$ and bags $(18.85 \%)$ (Figure 4). 